$$
\begin{gathered}
\text { 유화커드를 이용한 연어 패티의 } \mathrm{DHA} \text { 강화 } \\
\text { 및 이의 식품성분 특성 }
\end{gathered}
$$

허민수 · 김형준 ${ }^{1} \cdot$ 윤민석 $^{1} \cdot$ 박권현 $^{1} \cdot$ 신준호 $^{1} \cdot$ 이태기 ${ }^{2} \cdot$ 김정균 $^{1} \cdot$ 김진수 $^{1 *}$ 경상대학교 식품영양학과/해양산업연구소, ${ }^{1}$ 경상대학교 해양식품공학과/해양산업연구소,

${ }^{2}$ 전남도립대학교 생물식품과학부

\title{
DHA Enrichment of Salmon Patty using Emulsion Curd and Its Component Characteristics
}

\author{
Min Soo Heu, Hyung Jun Kim¹, Min Seok Yoon ${ }^{1}$, Kwon Hyun Park ${ }^{1}$, \\ Joon Ho Shin ${ }^{1}$, Tae-Gee Lee ${ }^{2}$, Jeong Gyun $\mathrm{Kim}^{1}$ and Jin-Soo Kim ${ }^{1}$ * \\ Department of Food and Nutrition/Institute of Marine Industry, \\ Gyeongsang National University, Jinju 660-701, Korea, \\ ${ }^{1}$ Department of Seafood Science and Technology/Institute of Marine Industry, \\ Gyeongsang National University, Tongyeong 650-160, Korea, \\ ${ }^{2}$ Department of Hotel Culinary \& Nutrition, Jeonnam Provincial College, \\ Damyang 517-802, Korea
}

To prepare high-quality fast foods using salmon, this study developed a docosahexaenoic acid (DHA)-enriched salmon patty, and compared its quality with soybean oil-added patty and commercial patty. The moisture and lipid contents of the DHA-enriched patty were $61.9 \%$ and $7.7 \%$, respectively. The moisture content was lower than in the commercial patty, while the lipid content was higher. The lipophilic and hydrophilic browning indices of the DHA-enriched patty were 0.10 and 0.05 , respectively, which were lower than those of the commercial patty. The DHA-enriched patty had 5\% less trichloroacetic acid (TCA)-soluble nitrogen than the commercial patty, and it was firmer. There were no differences in the proximate composition, browning indices, TCA-soluble nitrogen content, and hardness between the soybean-added and DHA-enriched patties prepared in this experiment. Examining the fatty acid compositions of the patties, the saturated acid and monoenoic acid compositions decreased in the following order: DHA-enriched patty $>$ soybean oil-added patty $>$ commercial patty, while the polyenoic acid composition increased in that order. The total amino acid content of the DHA-enriched patty was $19.13 \mathrm{~g} / 100 \mathrm{~g}$, which was $32 \%$ higher than that of the commercial patty $(14.47 \mathrm{~g} / 100 \mathrm{~g})$. No enriching effect of minerals would be expected on eating a 100 g DHA-enriched patty, except for phosphorus. The sensory evaluation indicated that the DHA-enriched patty was superior in color and taste to the commercial patty, while there was no difference in flavor between the patties.

Key words: Salmon, Patty, Fish patty, Emulsion curd, DHA

서 론

패티 (patty)는 돈육 및 우육과 같은 다진 축육에 여러 가지 부원료를 첨가하여 둥글면서 납작하게 만든 요리로 대표적인 패스트 푸드 (fast foods)이다. 최근 우리나라에서는 지역균형 발전과 같은 국가 정책의 변화와 더불어 사회적 변화와 경제 적 발전으로 핵가족화, 맞벌이 주부 및 단독 세대의 대거 등장 등과 같은 요인이 발생하고 교통난이 심각하게 발생하고 있 다. 따라서 패티와 같은 패스트 푸드의 수요는 사회적, 경제적 변화에 따른 요인과 함께 국민들의 식생활이 서구화되면서 급증하고 있다. 하지만, 현재 시판되고 있는 패티의 대부분은 축산물을 소재로 하여 제조되어 건강을 우려하는 소비자들은 비만 야기는 물론이고, 순환기계 계통의 성인병과 조류 독감,

\footnotetext{
*Corresponding author: jinsukim@gnu.ac.kr
}

돼지 콜레라 및 광우병 등과 같은 여러 가지 질병에 대한 우려로 섭취를 주저하고 있다 (Heu et al., 2007). 이러한 일면에 서 수산물로 패티를 제조하는 경우 수산물의 영양성분이 축육 과 유사할 뿐만이 아니라 각종 무기성분을 함유하고 있고, 조류 독감, 돼지 콜레라 및 광우병 등과 같은 질병의 우려 (Metha, 1987; Erkan and Ozden, 2007)가 없어 축육 패티를 대체할 수 있으리라 보아진다. 여러 가지 수산가공 자원 중 하나인 연어 (Oncorhynchus kuta)는 연어과이면서 바다에서 성장하여 산란기에 민물로 돌아오는 오는 대표적인 회귀성 어종으로, 몸이 길고 옆으로 납작하면서 입이 크며, 회귀 시 어획된 경우 전장이 일반적으로 $60 \sim 80 \mathrm{~cm}$ 에 이른다 $(\mathrm{Kim}$ et al., 2007). 일반적으로 대부분의 수산가공자원은 자연산이 어서 어획량을 예측할 수 없고, 어획시기도 특정시기로 한정 되어 있어 농축산 가공자원에 비하여 계획 생산에 제한을 
받고 있다. 하지만, 연어는 노르웨이 및 칠레 등에서 양식한 양식자원과 미미하지만 근년에 우리나라에서도 성공한 일부 양식자원을 이용함으로 인하여 계절에 관계없이 수확량을 조절할 수 있어 계획적인 수산가공 자원으로 공급이 가능하 다. 따라서, 연어는 수산가공학적인 측면에서 원료 확보에 어려움이 없으면서, 가공적성이 우수하고, 비린내가 적어 축 육에 익숙한 미국 및 유럽의 소비자들은 물론이며, 서구식에 익숙한 우리나라 신세대들과 건강을 우려하는 기성세대의 경우도 선호하고 있어 소비자 선호도 면에서도 고급 어종이 다. 이로 인하여 연어는 대부분이 스테이크 등과 같은 소재와 더불어 훈제품 및 통조림 등과 같은 완제품으로 가공 및 유통 되고 있으나, 이용 확대를 위하여 패티와 같은 다양한 서구식 의 개발이 절실하다.

한편, 축산가공품은 제조 중에 사용한 축산가공 원료에 따 라 제품의 성분이 달라질 수 있어 제품 성분의 균일화를 위하 여 반드시 표준화 공정을 도입하고 있다 (Kim et al., 2008). 일반적으로 수산물은 어획시기, 장소 및 어획물의 연령 등에 따라 여러 가지 성분의 조성, 특히 지질 조성이 다르다. 따라서 수산가공품은 제조 중에 사용한 원료의 종류에 따라 제품의 성분이 확연히 달라질 수 있어 제품성분의 균일화를 위한 표준화 공정이 반드시 도입되어야 하나 실제 이런 공정의 도입은 전혀 시도되지 않고 있다. 일반적으로 패티의 성분 표준화는 유화커드 (emulsion curd)에 의하여 실시하고 있다 (Ihm et al., 1992). 유화커드는 대두단백을 유화제 (emulsifier) 로 하여 기름과 물을 적당비율에서 혼합할 수 있어 지질함량 이 많은 원료로 패티를 제조하는 경우 유화커드 제조 시에 지질의 비율을 적게 하여 제조한 다음 혼합하고, 지질함량이 적은 원료로 패티를 제조하는 경우 유화커드 제조 시에 지질 의 비율을 높게 하여 제조한 다음 혼합하여 최종 제품인 패티 의 표준화를 시도한다. 이러한 일면에서 유화커드 제조 시에 사용하는 지질원인 대두유 대신에 건강 기능성 지질성분 (Gogus and Smith, 2010)으로 널리 알려져 있는 eicosapentaenoic acid (EPA, 20:5) 및 docosahexaenoic acid (DHA, 22:6)가 다량 함유되어 있는 오징어유 (Kim et al., 1997) 를 이용한다면 패티의 건강 기능성 개선에 도움이 되리라 생각된다.

한편, 연어를 이용한 여러 가지 가공품의 제조에 관한 연구 로는 프로타민 (protamine) (Joo et al., 2000), FPC (fish protein concentrates) (Lee et al., 1998) 및 조미가공품 (You, 1997) 등 뿐 만이 아니라 신세대의 기호에 맞춘 햄버거용 패티의 제조 (Heu and Kim, 2009) 등도 있다. 하지만, Kim at al. (Heu and Kim, 2009)에 의하여 진행된 연어 패티의 제조에 관한 연구도 단지 품질 표준화를 위하여 대두단백질, 대두유 및 물로 제조한 유화커드를 첨가한 정도에 그쳐, 건강 기능성 개선을 위하여 연어 패티의 DHA 강화를 시도한 연구는 전무 한 실정이다.

본 연구에서는 연어를 이용하여 고품질 패스트 푸드의 제조 를 위한 일련의 연구로 건강 기능성 지질성분인 $\mathrm{DHA}$ 를 강화 한 연어 패티의 개발을 시도하였고, 아울러 이의 품질 특성을
대두유로 제조한 유화커드 첨가 연어 패티와 시판 돈육 패티 와 비교하여 살펴보았다.

\section{재료 및 방법}

재료

연어 패티의 제조를 위한 주원료인 연어 근육은 2009년 4월에 부산광역시 사하구 소재 우영수산(주)에서 구입하여 냉동실 $\left(-25^{\circ} \mathrm{C}\right)$ 에 보관하여 두고 실험에 사용하였다.

그리고, 연어 패티의 제조를 위한 부원료 중 식염 [(주) 산내들식품] , 난황을 분리하기 위하여 사용한 계란, 빵가루 [(주) 동원], 쇠고기다시다 [(주) 백설] 및 대두유 [(주) 사 조해표] 는 2009년 4월에 경상남도 통영시 소0재 마트에서 구입하여 사용하였고, 분리 대두단백, 양파가루, 마늘가루와 같은 향신료, sorbitol (DT Sorni Berlian Co.) 및 중합인산염은 2009년 3월에 경상남도 양산시 소재 (주) MSC에서 구입하여 사용하였으며, $\mathrm{EPA}$ 및 $\mathrm{DHA}$ 강화를 목적으로 이용한 $\mathrm{DHA}$ 농축 오징어 내장유(오징어 간유로부터 농축한 것으로 $\mathrm{DHA}$ $27 \%$, EPA $12-15 \%$ 함유된 지질)는 2008년 2월에 경상북도 포항시 소재 동우수산 (주)로부터 구입하여 사용하였다.

유화커드의 제조 및 이를 이용한 연어 패티의 제조

햄버거용 패티의 지질함량을 조절할 목적으로 사용하고자 하는 유화커드는 물 $80 \mathrm{~mL}$ 에 유화제인 대두단백질 $16 \mathrm{~g}$ 을 가하고 2 분동안 교반 $(4,000 \mathrm{rpm})$ 한 다음 $\mathrm{DHA}$ 농축유 또는 대두유 $41.6 \mathrm{~g}$ (45 mL에 해당)을 각각 서서히 가하면서 교반 $(5,000 \mathrm{rpm})$ 하여 제조하였다.

유화커드 첨가 연어 패티는 마쇄 연어 근육 중량에 대하여 지질함량을 $7.5 \%$ 로 조절하기 위하여 유화커드 $(16.0 \%)$, 식염 (2.0\%), sorbitol $(2.0 \%)$, 중합인산염 $(0.3 \%)$, 조미료 $(0.5 \%)$, 양 파분말 $(0.6 \%)$, 마늘분말 $(0.6 \%)$, 난황 $(4.0 \%)$ 을 각각 첨가한 다음 혼합, 성형 (직경 $85 \mathrm{~mm}$ 의 원형)하고, 이를 계란 노른자와 빵가루 $\left(8.0^{\circ}\right)$ 를 차례로 입힌 후 튀김 $\left(180 \pm 5^{\circ} \mathrm{C}, 2\right.$ 분 $)$ 처리하여 제조하였다. 이 때 대두유로 제조한 유화커드 첨가 연어 패티 의 경우 이하 대두유 첨가 연어 패티로 칭하였고, DHA 농축 오징어 내장유로 제조한 유화커드 첨가 연어 패티의 경우 이하 DHA 강화 연어 패티로 칭하였다. 이와 같은 공정으로 제조한 이들 연어 패티는 색도의 전단면 측정용, 경도 측정용 및 관능검사 판정용 시료의 경우 튀김 처리한 것을 사용하였 고, 기타 물리화학적 특성을 검토하기 위한 시료의 경우 튀김 처리 전의 제품을 시료로 하였다.

일반성분, $\mathrm{pH}$ 및 휘발성염기질소

일반성분은 $\mathrm{AOAC}$ 법 (1995)에 따라 수분은 상압가열건조 법, 조단백질은 semimicro Kjeldahl법, 조지방은 Soxhlet법에 따라 측정하였고, 회분은 건식회화법으로 측정하였다. 휘발성 염기질소는 Conway unit를 사용하는 미량확산법 (Ministry of Social Welfare of Japan, 1960)으로 측정하였고, $\mathrm{pH}$ 는 시료에 10 배량의 탈이온수를 가한 다음 $\mathrm{pH}$ meter (model 691, Metrohm, Swiss)로 측정하였다. 
색조 및 갈변도

색조는 직시색차계 (ZE 2000, Nippon Denshoku Industries Co., Japan)를 이용하여 표면과 평형되게 절단한 전단면(튀김 후 시료 이용)의 Hunter $\mathrm{L}, \mathrm{a}, \mathrm{b}$ 및 $\triangle \mathrm{E}$ 값을 측정하였다. 이 때 표준백판은 $\mathrm{L}$ 값이 96.82 , a값이 -0.39 및 $\mathrm{b}$ 값이 0.63 이었다.

그리고, 갈변도는 Chung and Toyomidzu의 방법 (1976)에 따라 지용성 갈변도와 수용성 갈변도로 나누어 측정하였다. 갈변도 측정을 위한 시료는 지용성 갈변도의 경우 마쇄 패티 에 5 배량 $(\mathrm{v} / \mathrm{w})$ 의 chloroform-methanol $(2: 1, \mathrm{v} / \mathrm{v})$ 을 가하고 균질 화시켜 여과 및 chloroform 층을 분리하여 제조하였고, 수용성 갈변도의 경우 chloroform-methanol 추출 잔사에 대하여 5 배량 $(\mathrm{v} / \mathrm{w})$ 의 증류수를 가하고 균질 및 여과하여 제조하였다. 이들 지용성 및 수용성 갈변도는 분광광도계 (UV-140-02, Shimadzu Co., Japan)로 $430 \mathrm{~nm}$ 에서 측정한 흡광도로 나타내었다.

Trichloroacetic acid (TCA) 가용성 질소

$\mathrm{TCA}$ 가용성 질소 함량은 일정량 (약 $10 \mathrm{~g}$ )의 원료에 $20 \%$ $\mathrm{TCA} 30 \mathrm{~mL}$ 를 가하여 균질화 $(10$ 분 $)$ 하고 정용 $(100 \mathrm{~mL})$ 및 원심분리 $(3,000 \mathrm{rpm}, 10$ 분 $)$ 한 다음 이의 상층액을 시료로 하여 AOAC법 (1995)에 따라 semimicro Kjeldahl법으로 측정 하였다.

\section{경도}

경도 측정은 Park and Lee (2005)가 언급한 방법에 따라 측정하였다. 패티의 경도 측정은 패티를 튀긴 후 일정한 크기 $(2.0 \times 2.0 \times 1.2 \mathrm{~cm})$ 로 정형한 다음 rheometer $(\mathrm{CR}-100 \mathrm{D}$, Sun Scientific Co., Japan)로 측정하였다. 이때 load cell은 $10 \mathrm{~kg}$, chart speed는 $60 \mathrm{~mm} / \mathrm{min}$, adapter는 절단용 (No. 9)을 설치하여 사용하였다.

지방산 조성, 총 아미노산 및 무기질의 함량

지방산 조성은 Bligh and Dyer법(1959)으로 추출한 시료 지질을 이용하여 AOCS법 (1990)에 따라 지방산 메틸에스테 르화한 후에 capillary column (Supelcowax-10 fused silica wall-coated open tubular column, $30 \mathrm{~m} \times 0.25 \mathrm{~mm}$ I.d., Supelco Japan Ltd., Tokyo)이 장착된 gas chromatography (Shimadzu $14 \mathrm{~A}$; carrier gas, He; detecter, FID)를 이용하여 분석하였다. 분석조건은 injector 및 detector (FID) 온도를 각각 $250^{\circ} \mathrm{C}$ 로 하고, 칼럼온도는 $230^{\circ} \mathrm{C}$ 까지 승온시켜, 15 분간 유지하였다. Carrier gas는 $\mathrm{He}\left(1.0 \mathrm{~kg} / \mathrm{cm}^{2}\right)$ 을 사용하였으며, split ratio는 1:50으로 하였다. 지방산의 동정은 표준지방산(Applied Science Lab. Co., USA)과의 retention time을 비교하여 실시하 였다.

총 아미노산의 분석을 위한 시료는 적정량의 시료 $(50 \mathrm{mg})$ 에 $6 \mathrm{~N} \mathrm{HCl} 2 \mathrm{~mL}$ 를 ampoule에 넣고, 밀봉한 후 가수분해 $\left(110^{\circ} \mathrm{C}, 24\right.$ 시간)한 다음 glass filter로 여과, 감압건조 및 구연산 나트륨 완충액 $(\mathrm{pH}$ 2.2)으로 정용 $(25 \mathrm{~mL})$ 하여 시료를 조제하 였다. 그리고, 총 아미노산 분석은 이의 일정량을 사용하여 아미노산 자동분석기 (Biochrom 30, Parmacia Biotech., England)로 분석하였다.
무기질은 Tsutagawa et al. (1994)이 실시한 방법에 따라 질산 으로 유기질을 습식 분해하여 시료를 조제한 다음 inductively coupled plasma spectrophotometer (ICP, Atomscan 25, TJA)로 분석하였다.

\section{관능검사 및 통계처리}

관능검사는 맛, 조직감 및 색조에 잘 훈련된 10 인의 pannel member를 구성한 다음 튀김 처리한 시판 돈육 패티의 맛, 조직감 및 색조를 기준점인 4점으로 하고, 시제 연어 패티 제품이 이보다 우수한 경우 5-9점으로, 이보다 못한 경우 3-1점 으로 하는 9단계 평점법으로 상대평가하여 평균값으로 나타 내었다. 그리고, 이들의 값은 ANOVA test를 이용하여 분산분 석한 후, Duncan의 다중위검정 (Steel and Torrie, 1980)으로 최소 유의차 검정 $(5 \%$ 유의 수준)을 실시하여 나타내었다.

Table 1. Proximate composition, $\mathrm{pH}$ and volatile basic nitrogen (VBN) contents of emulsion curd-added salmon patties and commercial patty

\begin{tabular}{clccc}
\hline \multirow{2}{*}{ Component } & \multicolumn{3}{c}{ Emulsion curd-added salmon patty } & \\
\cline { 2 - 4 } & $\begin{array}{c}\text { Soybean } \\
\text { oil-added } \\
\text { emulsion curd }\end{array}$ & $\begin{array}{c}\text { Squid viscera } \\
\text { oil-added } \\
\text { emulsion curd }\end{array}$ & $\begin{array}{c}\text { Commercial } \\
\text { patty }{ }^{2}\end{array}$ \\
\hline Proximate & Moisture & $62.2 \pm 0.6$ & $61.9 \pm 0.2$ & $63.4 \pm 0.7$ \\
composition & Crude protein & $18.0 \pm 0.1$ & $17.8 \pm 0.2$ & $15.6 \pm 0.1$ \\
$(\mathrm{~g} / 100 \mathrm{~g})$ & Crude lipid & $7.4 \pm 0.4$ & $7.7 \pm 0.9$ & $6.3 \pm 0.1$ \\
& Ash & $2.3 \pm 0.0$ & $2.3 \pm 0.2$ & $2.1 \pm 0.1$ \\
$\mathrm{pH}$ & 7.50 & 7.59 & 6.15 \\
VBN $(\mathrm{mg} / 100 \mathrm{~g})$ & $9.8 \pm 0.1$ & $9.6 \pm 0.1$ & $21.9 \pm 0.1$ \\
\hline
\end{tabular}

${ }^{1)}$ These emulsion curds were prepared by mixing soybean protein, water, soybean oil or squid viscera oil.

${ }^{2)}$ These data were quoted by Heu and Kim (2009).

$$
\text { 결과 및 고찰 }
$$

일반성분, $\mathrm{pH}$ 및 휘발성염기질소

$\mathrm{DHA}$ 강화 연어 패티의 일반성분, $\mathrm{pH}$ 및 휘발성염기질소 함량을 대두유 첨가 연어 패티 및 시판 돈육 패티의 그것들과 비교한 결과는 Table 1과 같다. DHA 강화 연어 패티의 일반성 분은 수분 함량이 $61.9 \%$, 조단백질 함량이 $17.8 \%$, 조지방 함량 이 $7.7 \%$, 조회분 함량이 $2.3 \%$ 로, 시판 돈육 패티의 일반성분 (수분 함량이 $63.4 \%$, 조단백질 함량이 $15.6 \%$, 조지방 함량이 $6.3 \%$, 조회분 함량이 $2.1 \%$ )에 비하여 제품의 종류에 관계없이 조단백질 함량 및 조지방 함량의 경우 높았고, 수분 함량의 경우 낮았으며, 조회분 함량의 경우 차이가 없었다. 이와 같이 패티의 수분 함량 결과로 미루어 보아 조직감은 DHA 강화 연어 패티가 시판 패티에 비하여 다소 딱딱하리라 추정되었 다. 그러나, DHA 강화 연어 패티의 일반성분과 대두유 첨가 연어 패티의 일반성분 (수분 함량이 $62.2 \%$, 조단백질 함량이 $18.0 \%$, 조지방 함량이 $7.4 \%$, 조회분 함량이 $2.3 \%$ ) 간에는 $5 \%$ 유의수준에서 차이가 없었다. 이와 같이 두 종의 시제 연어 패티와 시판 돈육 패티 간에 일반성분의 차이는 주원료 및 
부원료의 종류, 배합비, 유화커드의 첨가 유무 및 가공방법 등에 의한 차이 때문이라 판단되었다. 한편, $\mathrm{DHA}$ 강화 연어 패티의 $\mathrm{pH}$ 및 휘발성 염기질소 함량은 각각 7.59 및 $9.6 \mathrm{mg} / 100 \mathrm{~g}$ 을 나타내었는데, 이들은 시판 돈육 패티의 $\mathrm{pH}$ 및 휘발성 염기질 소 함량인 각각 6.15 및 $21.9 \mathrm{mg} / 100 \mathrm{~g}$ 에 비하여 $\mathrm{pH}$ 는 높았으나 휘발성 염기질소 함량은 낮아 차이가 있었는데, 이 또한 주원 료의 신선도 이외에 첨가물의 종류 및 제조방법 등에 의한 영향이라 판단되었다. 그러나, DHA 강화 연어 패티와 대두유 첨가 연어 패티 간의 $\mathrm{pH}$ 및 휘발성 염기질소 함량은 $5 \%$ 유의수 준에서 차이가 없었다.

한편, 연어의 수은과 오징어 내장유의 카드뮴이 이를 주원 료로 하여 제조한 DHA 강화 연어 패티 제품에 중금속적인 문제가 있을 것으로 판단하여 DHA 강화 연어 패티 제품의 수은과 카드늄을 분석한 결과 이들 중금속은 검출되지 않았다 (데이타 미제시).

Table 2. Hunter color values of emulsion curd-added salmon patties and commercial patty

\begin{tabular}{|c|c|c|c|}
\hline \multirow[b]{2}{*}{$\begin{array}{l}\text { Hunter } \\
\text { color }\end{array}$} & \multicolumn{2}{|c|}{ Emulsion curd-added salmon patty ${ }^{1)}$} & \multirow[b]{2}{*}{$\begin{array}{c}\text { Commercial } \\
\text { patty }^{2}\end{array}$} \\
\hline & $\begin{array}{l}\text { Soybean oil-added } \\
\text { emulsion curd }\end{array}$ & $\begin{array}{c}\text { Squid viscera } \\
\text { oil-added emulsion } \\
\text { curd }\end{array}$ & \\
\hline $\mathrm{L}$ & $45.2 \pm 2.4$ & $45.2 \pm 1.8$ & $50.10 \pm 0.52$ \\
\hline a & $2.8 \pm 0.7$ & $3.5 \pm 1.0$ & $7.30 \pm 0.13$ \\
\hline b & $15.0 \pm 1.3$ & $16.3 \pm 0.5$ & $16.56 \pm 0.22$ \\
\hline$\triangle E$ & $54.5 \pm 2.0$ & $54.8 \pm 1.8$ & $49.99 \pm 0.53$ \\
\hline
\end{tabular}

${ }^{1)}$ The emulsion curd was prepared by mixing soybean protein, water, soybean oil or squid viscera oil.

${ }^{2)}$ These data were quoted from the results of Heu and Kim (2009).

\section{색조 및 갈변도}

튀김 처리한 DHA 강화 연어 패티 절단면의 헌터 색조를 역시 튀김처리한 대두유 첨가 연어 패티와 시판 돈육 패티 절단면들의 헌터 색조와 비교한 결과는 Table 2와 같다. 헌터 색조는 DHA 강화 첨가 연어 패티가 명도의 경우 45.21, 적색도 의 경우 3.50 , 황색도의 경우 16.30 , 그리고 색차의 경우 54.84 로, 시판 돈육 패티의 헌터 색조 (명도가 50.10, 적색도가 7.30, 황색도가 16.56 , 색차가 49.99)에 비하여 명도, 적색도 및 황색 도의 경우 낮았고, 색차는 높았다. 그러나 $\mathrm{DHA}$ 강화 연어 패티의 헌터 색조와 대두유 첨가 연어 패티의 헌터 색조 (명도 가 50.10, 적색도가 7.30, 황색도가 16.56 , 색차가 49.99) 간에는 $5 \%$ 유의수준에서 차이가 없었다. 이와 같이 유화커드의 소재 로 사용한 대두유와 DHA 농축 오징어 내장유 간에 색조가 관능적으로 다소 차이가 있었음에도 불구하고 이로부터 제조 한 유화커드 첨가 두 종의 패티 간에 색조가 $5 \%$ 유의수준에서 차이가 없었던 것은 유지를 소재로 하여 유화커드를 제조하는 경우 정제 유지의 소재에 관계없이 일반적으로 백색을 나타내 어 차이를 나타내지 않기 때문이라 판단되었다. 한편, 시제 패티와 시판 패티 간에 헌터 색조의 결과는 주원료의 적색육
과 부원료의 지질산화, 색소의 첨가 유무 및 유화커드가 나타 내는 색상에 의한 영향 (Heu and Kim, 2009)이 컸으리라 판단 되었다.

$\mathrm{DHA}$ 강화 연어 패티의 갈변도를 시판 돈육 패티 및 대두유 첨가 연어 패티의 갈변도들과 비교한 결과는 Fig. 1 과 같다. 지용성과 수용성으로 나누어 살펴 본 갈변도는 DHA 강화유 첨가 연어 패티가 각각 0.10 및 0.05 로 시판 돈육 패티의 각각 0.27 및 0.15 에 비하여 모두 낮아 차이가 있었으나, 대두유 첨가 연어 패티의 각각 0.11 및 0.06 에 비하여 $5 \%$ 유의수준에 서 차이가 없었다. 한편, 패티의 갈변도는 시제 두 종류의 연어 패티 및 시판 돈육 패티와 같이 패티의 종류에 관계없이 전제품이 모두 지용성 갈변도가 수용성 갈변도에 비하여 높아 패티의 갈변은 Maillard 반응에 의한 수용성 갈변이라기 보다 는 지질에 의한 지질 산화 갈변이라 추정되었다.

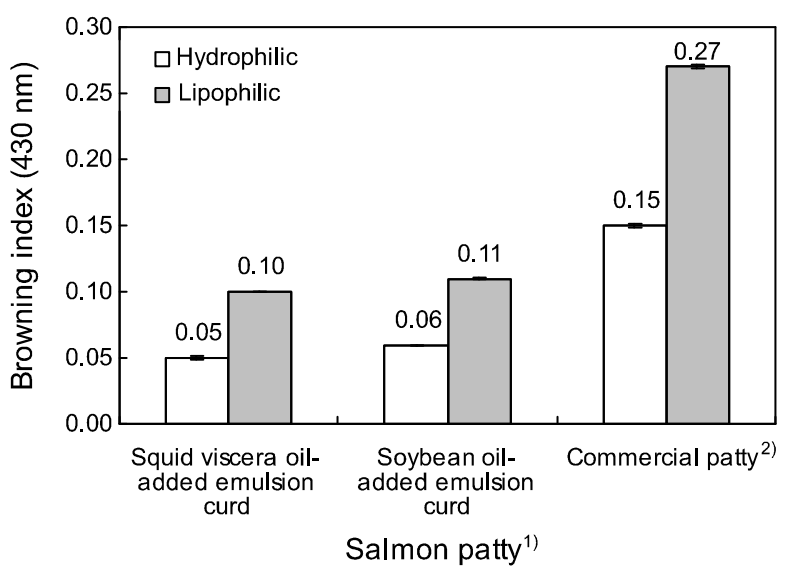

Fig. 1. Browning indices of emulsion curd-added salmon patties and commercial patty.

${ }^{1)}$ The emulsion curd was prepared by mixing soybean protein, water, soybean oil or squid viscera oil.

${ }^{2)}$ These data were quoted by Heu and Kim (2009).



Fig. 2. Trichloroacetic acid (TCA)-soluble nitrogen contents of emulsion curd-added salmon patties and commercial patty. ${ }^{1)}$ The emulsion curd was prepared by mixing soybean protein, water, soybean oil or squid viscera oil.

${ }^{2)}$ These data were quoted by Heu and Kim (2009). 


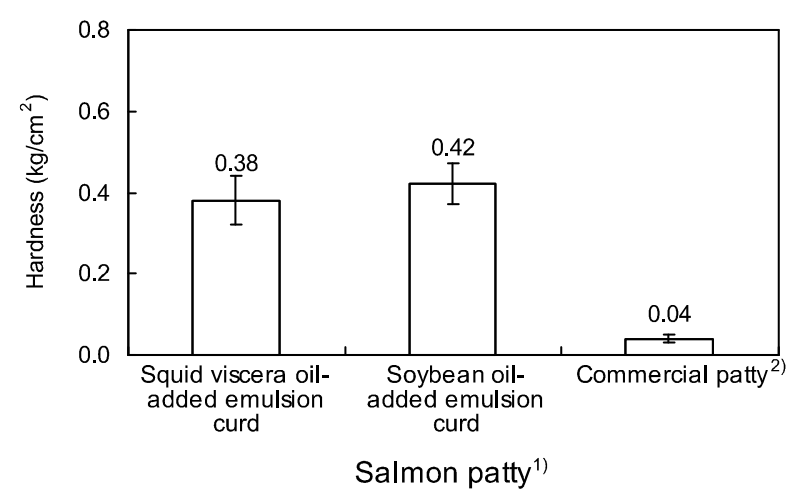

Fig. 3. Hardness of emulsion curd-added salmon patties and commercial patty.

${ }^{1)}$ The emulsion curd was prepared by mixing soybean protein, water, soybean oil or squid viscera oil.

${ }^{2)}$ These data were quoted by Heu and Kim (2009).

Table 3. Fatty acid composition of emulsion curd-added salmon patties and commercial patty

(Area \%)

\begin{tabular}{|c|c|c|c|c|c|c|c|}
\hline \multirow{2}{*}{$\begin{array}{l}\text { Fatty } \\
\text { acid }\end{array}$} & \multicolumn{2}{|c|}{$\begin{array}{l}\text { Emulsion } \\
\text { curd-added salmon } \\
\text { patty }\end{array}$} & \multirow{2}{*}{$\begin{array}{c}\text { Commercial } \\
\text { patty }^{2}\end{array}$} & \multirow{2}{*}{$\begin{array}{l}\text { Fatty } \\
\text { acid }\end{array}$} & \multicolumn{2}{|c|}{$\begin{array}{l}\text { Emulsion curd-added } \\
\text { salmon patty }\end{array}$} & \multirow{2}{*}{ Commercia } \\
\hline & $\begin{array}{c}\text { Squid } \\
\text { viscera }\end{array}$ & $\begin{array}{c}\text { Soybean } \\
\text { oil }\end{array}$ & & & $\begin{array}{c}\text { Squid } \\
\text { viscera }\end{array}$ & $\begin{array}{c}\text { Soybean } \\
\text { oil }\end{array}$ & \\
\hline 14:0 & 2.4 & 1.5 & 1.4 & $18: 2 n-6$ & 8.4 & 14.6 & 19.7 \\
\hline 15:0 & 0.2 & 0.2 & - & $18: 2 n-4$ & 0.2 & 0.2 & 0.2 \\
\hline $16: 0$ & 18.7 & 21.2 & 21.4 & $18: 3 n-6$ & 0.2 & 0.2 & 0.2 \\
\hline 17:0 & 0.2 & 0.2 & 0.4 & $18: 3 n-4$ & 0.1 & 0.2 & - \\
\hline 18:0 & 4.7 & 6.6 & 8.1 & $18: 3 n-3$ & 0.8 & 3.9 & 1.8 \\
\hline 20:0 & 0.1 & 0.2 & 0.1 & $18: 4 n-3$ & 1.0 & 0.3 & 0.3 \\
\hline Saturated & 26.3 & 29.9 & 31.4 & $18: 4 n-1$ & 0.2 & 0.2 & 0.1 \\
\hline $16: 1 n-7$ & 4.3 & 2.7 & 3.7 & $20: 2 n-6$ & 0.5 & 0.3 & 0.2 \\
\hline $18: 1 n-9$ & 24.6 & 32.5 & 40.9 & $20: 4 n-6$ & 1.7 & 0.9 & 0.3 \\
\hline 18:1n-7 & 3.3 & 2.9 & 0.2 & $20: 4 n-3$ & 0.6 & 0.3 & - \\
\hline $20: 1 n-9$ & 3.3 & 1.1 & 0.5 & $20: 5 n-3$ & 7.9 & 2.6 & - \\
\hline $22: 1 n-9$ & 1.3 & 0.4 & - & $21: 5 n-3$ & 0.2 & 0.1 & - \\
\hline Monoenes & 36.8 & 39.6 & 45.3 & $22: 5 n-6$ & 0.6 & 0.6 & - \\
\hline $16: 3 n-4$ & 0.2 & 0.1 & 0.4 & $22: 5 n-3$ & 1.0 & 1.2 & - \\
\hline $16: 4 n-3$ & 0.1 & - & 0.1 & $22: 6 n-3$ & 12.2 & 4.5 & - \\
\hline $16: 4 n-1$ & 1.0 & 0.3 & - & Polyenes & 36.9 & 30.5 & 23.3 \\
\hline
\end{tabular}

${ }^{1)}$ The emulsion curd was prepared by mixing soybean protein, water, soybean oil or squid viscera oil.

${ }^{2)}$ These data were quoted by Heu and Kim (2009).

$\mathrm{TCA}$ (trichloroacetic acid) 가용성 질소 함량

튀김처리 전 $\mathrm{DHA}$ 강화 연어 패티의 $\mathrm{TCA}$ 가용성 질소 함량 을 대두유 첨가 연어 패티 및 시판 돈육 패티의 TCA 가용성 질소 함량들과 비교한 결과는 Fig. 2 와 같다. TCA 가용성 질소 함량은 DHA 강화 연어 패티가 $271.3 \mathrm{mg} / 100 \mathrm{~g}$ 으로, 시판 돈육 패티의 $285.7 \mathrm{mg} / 100 \mathrm{~g}$ 에 비하여 약간 낮았고, 대두유 첨가 연어 패티의 $279.9 \mathrm{mg} / 100 \mathrm{~g}$ 에 비하여 $5 \%$ 유의수준에서 차이 가 없었다. 한편, 맛의 역치 (Heu et al., 2007)를 고려하지 않고 $\mathrm{TCA}$ 가용성 질소 함량 만으로 미루어 본 시제 연어 패티의
맛 강도는 시판 돈육 패티와는 유사하리라 추정되었다.

경도

튀김처리한 DHA 강화 연어 패티의 경도를 역시 튀김처리 한 시판 돈육 패티와 대두유 첨가 연어 패티의 경도들과 비교 한 결과는 Fig. 3 과 같다. 경도는 DHA 강화유 첨가 연어 패티가 $0.38 \mathrm{~kg} / \mathrm{cm}^{2}$ 으로, 대두유 첨가 연어 패티의 $0.42 \mathrm{~kg} / \mathrm{cm}^{2}$ 에 비하 여 낮았으나 $5 \%$ 유의수준에서는 차이가 없었다. 그러나, 두 종류의 시제 연어 패티의 경도는 시판 돈육 패티의 경도인 $0.04 \mathrm{~kg} / \mathrm{cm}^{2}$ 에 비하여는 훨씬 높아 차이가 있었다. 이와 같이 두 종류의 시제 연어 패티의 경도가 시판 돈육 패티에 비하여 높은 것은 여러 가지 원인이 있겠으나 두 종류의 시제 연어 패티와 시판 돈육 패티 간에 수분 함량의 차이도 크게 작용하 였으리라 추정되었다(Kim and Park, 2000). 이상에서 살펴 본 패티의 경도 결과로 미루어 보아 시제 연어 패티는 시판 돈육 패티에 비하여 소비자들이 다소 딱딱한 느낌을 받으리라 추정 되었다.

지방산 조성, 총 아미노산 및 무기질의 함량

$\mathrm{DHA}$ 강화 연어 패티의 지방산 조성을 분석한 다음 대두유 첨가 연어 패티와 시판 돈육 패티의 지방산 조성들을 비교하 여 나타낸 결과는 Table 3 과 같다. 패티의 지방산은 돈육 패티 의 경우 포화산이 5 종, 모노엔산이 4종, 그리고 폴리엔산이 10 종으로 총 19 종이 동정되었고, 대두유 첨가 연어 패티의 경우 포화산이 6종, 모노엔산이 5종 및 폴리엔산이 17종으로 총 28 종이 동정되었으며, DHA 강화 연어 패티의 경우 포화산 이 6종, 모노엔산이 5종 및 폴리엔산이 18종으로 총 29종이 동정되었다. 이와 같은 결과로 미루어 보아 패티의 총지질로 부터 동정된 지방산의 종류는 시제 두 종의 패티 간에는 차이 가 없었으나, 시제 연어 패티가 시판 패티에서 검출되지 않았 던 20:4n-3, 20:5n-3, 21:5n-3, 22:5n-6, 22:5n-3 및 22:6n-3와 같은 탄소수 20 개 이상의 고도불포화 지방산이 검출되어 확연 히 차이가 있었다. 시판 돈육 패티의 지방산 조성은 18:1n-9 (40.9\%)을 주로 하는 모노엔산이 $45.3 \%$ 로 가장 높았고, 다음 으로 $16: 0$ (21.4\%)를 주로 하는 포화산 (31.4\%) 및 18:2n-6 (19.7\%)를 주로 하는 폴리엔산 $(23.3 \%)$ 의 순이었다. 이에 반하 여 대두유 첨가 연어 패티의 지방산 조성은 $18: \ln -9$ (39.6\%)를 주로 하는 모노엔산이 $39.6 \%$ 로 가장 높았고, 다음으로 18:2n-6(14.6\%)을 주로 하는 폴리엔산 (30.5\%) 및 16:0를 주로 하는 포화산 $(29.9 \%)$ 의 순이었으며, DHA 강화 연어 패티의 지방산 조성은 22:6n-3 (12.2\%)를 주로 하는 폴리엔산이 $36.9 \%$ 로 가장 높았고, 다음으로 18:1n-9 (24.6\%)를 주로 하는 모노엔 산 $(36.8 \%)$ 및 $16: 0(18.7 \%)$ 를 주로 하는 포화산 $(26.3 \%)$ 의 순이었다. 이상의 결과로 미루어 보아 패티의 지방산 조성은 시판 패티에 비하여 시제 연어 패티가 주요 지방산이 증감함 에 따라 포화산과 모노엔산의 경우 감소하였고, 폴리엔산의 경우 증가하는 경향을 나타내었으며, 시제 연어 패티 간의 경우 DHA 강화 연어 패티가 대두유 첨가 연어 패티에 비하여 이러한 경향은 더욱 뚜렷하였다. 일반적으로 지질은 지방산의 구성 조성에 따라 질병을 야기하거나 건강에 도움주기도 한 
다. 즉, 지방산이 탄소수 18 이하인 포화산은 생체 내에서 acetyl-CoA로부터 쉽게 합성이 가능하면서 콜레스테롤보다 오히려 더 직접적인 동맥경화인자이거나 혈전증가 인자이이 어서 질병을 야기하는 인자로 분류된다 (The Korean Nutrition Society, 2000). 이에 반하여 EPA 및 DHA와 같은 지방산은 중성지방을 감소시키는 인자이어서 건강 기능성 지질로 분류 되기도 하며, 이들은 외인성이어서 식품을 통하여 섭취되거나 인체내에서 전구체로부터 생합성되어야 한다 (The Korean Nutrition Society, 2000). 이러한 일면에서 시판 패티, 대두유 첨가 연어 패티 및 $\mathrm{DHA}$ 강화 연어 패티가 질병을 야기할 수 있는 탄소수 18 이하의 포화 지방산의 경우 각각 $31.3 \%$, $29.7 \%$ 및 $26.2 \%$ 이었고, 건강 기능성을 가진 지방산 $(20: 5 n-3$ 및 22:6n-3) 조성의 경우 각각 미검출, $7.1 \%$ 및 $20.1 \%$ 이었다. 이와 같은 지방산 조성으로 미루어 보아 DHA 강화 연어 패티 가 시판 패티와 대두유 첨가 연어 패티에 비하여 탄소수 18 이하의 지방산 조성비가 낮으면서 건강 기능성을 가진 지방산 의 조성비는 월등히 높아 이 실험에서 대조구로 제조한 수산 패티 및 시판 축산 패티에 비하여 지질면에서는 건강 기능성 을 기대할 수 있으리라 추정되었다. 한편, 한국식품영양학회 (The Korean Nutrition Society, 2000)에서는 우리나라 국민의 균형된 지방산 섭취를 위하여 포화산/모노엔산/폴리엔산의 조성비를 $1 / 1 / 1$ 로 권장한 바 있는데, 시제 DHA 강화 연어 패티, 대두유 첨가 연어 패티 및 시판 돈육 패티의 이들에 대한 조성비는 각각 $0.71 / 1.00 / 1.00, \quad 0.98 / 1.30 / 1.00$ 및 $1.35 / 1.94 / 1.00$ 이었다. 이와 같은 결과로 미루어 보아 균형된 지방산 조성은 시판 돈육 패티에 비하여 $\mathrm{DHA}$ 강화 연어 패티 및 대두유 첨가 연어 패티와 같은 시제 연어 패티가 우수하였 고, 시제 연어 패티 간에는 지방산 조성비까지 고려하는 경우 $\mathrm{DHA}$ 강화 연어 패티가 대두유 첨가 연어 패티에 비하여 우수 하였다. 이상의 패티 유래 지질로부터 검출된 지방산 종류와 조성에 있어 차이는 패티의 제조를 위하여 사용한 돼지육과 연어육 유래 지방산 조성과 지질함량의 표준화를 위하여 사용 한 오징어 내장유 유래 DHA 농축유와 대두유의 지방산 조성 에 있어 차이가 있었기 때문이라 판단되었다 (Kim et al., 1997).

$\mathrm{DHA}$ 강화 연어 패티의 총아미노산 함량과 조성을 분석하 여 시판 돈육 패티의 그것들과 비교하여 나타낸 결과는 Table 4 와 같다. 패티의 총아미노산은 시판 패티 및 시제 연어 패티에 관계없이 17 종이 동정되었다. 총아미노산 함량은 시제 연어 패티가 $19.13 \mathrm{~g} / 100 \mathrm{~g}$ 으로, 시판 돈육 패티의 $14.47 \mathrm{~g} / 100 \mathrm{~g}$ 에 비하여 $32 \%$ 가 높았다. 한편, 총아미노산 중 $10 \%$ 이상을 차지 하는 주요 아미노산은 시제 연어 패티의 경우 aspartic acid (22.7\%) 및 glutamic acid (12.9\%)와 같은 2종이었고, 시판 돈육 패티의 경우 glutamic acid (16.9\%) 및 arginine (16.4\%)과 같은 2종으로, 패티의 종류에 따라 차이가 있었다. 그리고, 시판 패티 및 시제 연어 패티의 이들 주요 아미노산 조성은 총아미 노산 조성의 각각 $35.6 \%$ 및 $33.3 \%$ 를 차지하였다. 시제 연어 패티 및 시판 돈육 패티의 tryptophan을 제외한 9종의 필수아미 노산(threonine, valine, leucine, isoleucine, lysine, methionine, phenylalanine, histidine 및 arginine)은 각각 $45.0 \%$ 및 $47.5 \%$ 로
전체 아미노산의 약 절반을 차지하였고, 이 중 함량 및 조성비 가 가장 낮은 아미노산은 두 종류의 패티가 모두 methionine (각각 $1.6 \%$ 및 $2.7 \%$ )이어서 검출되지 않은 tryptophan을 제외 한다면 연어 패티의 제한 아미노산은 methionine으로 판단되 었다. 한편, 곡류 제한아미노산으로 알려져 있는 lysine 함량과 threonine (Kim et al., 2006) 함량은 시제 연어 패티의 경우 $1.70 \mathrm{~g} / 100 \mathrm{~g}$ 및 $0.87 \mathrm{~g} / 100 \mathrm{~g}$ 으로 시판 돈육 패티의 각각 0.48 $\mathrm{g} / 100 \mathrm{~g}$ 및 $0.45 \mathrm{~g} / 100 \mathrm{~g}$ 에 비하여 매우 높아 곡류를 주식으로 하는 동양권 국가에서 시제 연어 패티를 식용하는 경우 영양 균형적인 면에서 상당히 의미가 있다고 판단되었다.

Table 4. Total amino acid contents of emulsion curd-added salmon patty and commercial patty

$(\mathrm{g} / 100 \mathrm{~g})$

\begin{tabular}{ccc}
\hline \multirow{2}{*}{ Amino acid } & \multicolumn{2}{c}{ Patty } \\
\cline { 2 - 3 } & Commercial $^{2)}$ & Emulsion-added $^{1)}$ \\
\hline Aspartic acid & $1.00(6.9)^{3)}$ & $4.35(22.7)$ \\
Threonine & $0.45(3.1)$ & $0.87(4.5)$ \\
Serine & $0.66(4.6)$ & $0.81(4.2)$ \\
Glutamic acid & $2.45(16.9)$ & $2.47(12.9)$ \\
Proline & $1.17(8.1)$ & $0.74(3.9)$ \\
Glycine & $0.57(3.9)$ & $0.73(3.8)$ \\
Alanine & $0.67(4.6)$ & $0.96(5.0)$ \\
Cystine & $0.67(4.6)$ & $0.09(0.5)$ \\
Valine & $0.77(5.3)$ & $0.99(5.2)$ \\
Methionine & $0.23(1.6)$ & $0.52(2.7)$ \\
Isoleucine & $0.64(4.4)$ & $0.84(4.4)$ \\
Leucine & $1.01(7.0)$ & $1.33(7.0)$ \\
Tyrosine & $0.40(2.8)$ & $0.37(1.9)$ \\
Phenylalanine & $0.60(4.1)$ & $0.86(4.5)$ \\
Histidine & $0.33(2.3)$ & $0.57(3.0)$ \\
Lysine & $0.48(3.3)$ & $1.70(8.9)$ \\
Arginine & $2.37(16.4)$ & $0.93(4.9)$ \\
\hline Total & $14.47(99.9)$ & $19.13(100)$ \\
\hline
\end{tabular}

${ }^{1)}$ The emulsion curd was prepared by mixing soybean protein, water and squid viscera oil.

${ }^{2)}$ These data were quoted by Heu and Kim (2009).

3)The values in parentheses mean $\mathrm{g} / \mathrm{mg}$ total amino acid.

무기질은 필요량에 관계없이 부족한 경우 여러 가지 질병을 야기하는 등으로 인하여 적정량은 반드시 섭취되어야 하며, 바다에서 서식하는 수산물에 다양한 종류와 높은 함량이 함유 되어 있다. 이러한 일면에서 무기질 공급원으로 기대되는 시 제 DHA 강화 연어 패티의 철, 칼슘, 칼륨, 인 및 마그네슘의 함량과 조성을 분석한 다음 시판 돈육 패티의 그것들과 비교 하여 살펴 본 결과는 Table 5와 같다. 일반적으로 철은 혈액색 소, 근육색소, 간 및 내장 등에 존재하면서 적혈구 및 cytochrome과 같은 효소를 형성하고, 탄산가스나 산소를 운반 하며, $\beta$-carotene과 같은 provitamine이 vitamin A로 전환하는 과정이나 핵산의 일부인 purine 합성 등에서 촉매작용을 한다 고 알려져 있고, 칼슘은 뼈와 근육에 주로 존재하면서 신체 지지기능, 세포 및 효소의 활성화에 의한 근육의 수축 및 이완, 
Table 5. Mineral contents of emulsion curd-added salmon patties and commercial patty

\begin{tabular}{ccccc}
\hline & \multicolumn{4}{c}{ Patty } \\
\cline { 2 - 5 } & \multicolumn{3}{c}{ Emulsion curd-added $^{1)}$} & \multicolumn{2}{c}{ Commercial $^{2)}$} \\
$\mathrm{Fe}$ & 0.6 & \pm 0.0 & 1.8 & \pm 0.1 \\
$\mathrm{Ca}$ & 25.5 & \pm 0.3 & 39.5 & \pm 0.3 \\
$\mathrm{~K}$ & 234.4 & \pm 1.8 & 205.0 & \pm 0.5 \\
$\mathrm{P}$ & 211.2 & \pm 1.6 & 145.5 & \pm 0.9 \\
$\mathrm{Mg}$ & 32.5 & \pm 0.4 & 31.2 & \pm 1.8 \\
\hline
\end{tabular}

${ }^{1)}$ The emulsion curd was prepared by mixing soybean protein, water and squid viscera oil.

${ }^{2)}$ These data were quoted by Heu and Kim (2009).

Table 6. Results on the sensory evaluation of emulsion curd-added salmon patties and commercial patty

\begin{tabular}{|c|c|c|c|}
\hline \multirow{2}{*}{$\begin{array}{l}\text { Sensory } \\
\text { evaluation }\end{array}$} & \multicolumn{2}{|c|}{ Emulsion curd-added salmon patty } & \multirow{2}{*}{$\begin{array}{c}\text { Commercial } \\
\text { patty }\end{array}$} \\
\hline & $\begin{array}{l}\text { Soybean oil-added } \\
\text { emulsion curd }\end{array}$ & $\begin{array}{l}\text { DHA-enriched } \\
\text { emulsion curd }{ }^{1)}\end{array}$ & \\
\hline Color & $7.6 \pm 1.3^{a}$ & $7.5 \pm 1.1^{\mathrm{a}}$ & $4.0 \pm 0.0^{b}$ \\
\hline Flavor & $4.0 \pm 1.8^{\mathrm{a}}$ & $4.0 \pm 1.5^{\mathrm{a}}$ & $4.0 \pm 0.0^{\mathrm{a}}$ \\
\hline Taste & $6.8 \pm 1.0^{a}$ & $7.4 \pm 1.1^{\mathrm{a}}$ & $4.0 \pm 0.0^{b}$ \\
\hline
\end{tabular}

${ }^{1)}$ The emulsion curd was prepared by mixing soybean protein, water, soybean oil or squid viscera oil.

신경의 흥분과 자극전달, 혈액의 응고 및 여러 가지 심혈관계 질환의 예방에 관여하고 또한, 우리나라를 위시한 동양권 식 이 패턴에서 부족되기 쉬운 영양소로 알려져 있다 (The Korean Nutrition Society, 2000). 이와 같은 건강 기능성을 가진 철과 칼슘 함량은 시제 연어 패티가 각각 $0.6 \mathrm{mg} / 100 \mathrm{~g}$ 및 25.5 $\mathrm{mg} / 100 \mathrm{~g}$ 으로, 시판 돈육 패티의 각각 $1.8 \mathrm{mg} / 100 \mathrm{~g}$ 및 39.5 $\mathrm{mg} / 100 \mathrm{~g}$ 에 비하여 매우 낮았다. 칼름은 대부분이 근육세포 내에 존재하면서 삼투압 및 $\mathrm{pH}$ 의 조절, 신경 근육의 흥분성 유지, 뇨 중의 나트륨 이온의 배설을 증가시킴으로 인한 고혈 압과 동맥경화증 예방에 중요한 역할을 한다고 알려져 있고, 인은 뼈, 혈액, 인지질과 DNA, RNA 등의 핵산과 nucleotide 등에 분포되어 있으면서, 신체 지지기능, 신체의 에너지 발생 촉진, 뇌신경 성분, 산-염기의 평형을 조절하는 완충효과에 의한 정상 $\mathrm{pH}$ 유지, 대사과정에서 생긴 에너지의 저장과 이동 및 인산화 반응에 의한 여러 효소의 활성화 등과 같이 매우 중요한 생리기능을 담당하고 있으나 거의 모든 식품에 적정량 이 함유되어 있어 결핍의 우려가 적은 영양소로 알려져 있다 (The Korean Nutrition Society, 2000). 이와 같은 칼륨과 인 함량은 시제 연어 패티가 각각 $234.4 \mathrm{mg} / 100 \mathrm{~g}$ 및 $211.2 \mathrm{mg} / 100 \mathrm{~g}$ 으로 시판 돈육 패티의 각각 $205.0 \mathrm{mg} / 100 \mathrm{~g}$ 및 $145.5 \mathrm{mg} / 100 \mathrm{~g}$ 에 비하여 높아 차이가 있었다. 또한, 마그네슘은 뼈, 세포내액 및 외액에 주로 존재하면서 근육의 긴장 및 이완, 호기적 및 혐기적 에너지 대사작용, 효소의 활성화 등에 기여하는 것으 로 알려져 있다 (The Korean Nutrition Society, 2000). 이와 같은 마그네슘 함량은 시제 연어 패티와 시판 패티가 각각 $32.5 \mathrm{mg} / 100 \mathrm{~g}$ 및 $31.2 \mathrm{mg} / 100 \mathrm{~g}$ 으로 거의 차이가 없었다.
한편, Kim et al. (2006)은 위의 무기질에 대한 여러 가지 건강 기능 효과를 기대하기 위한 일일 섭취량으로 철의 경우 12 $\mathrm{mg}$, 칼륨의 경우 $4 \mathrm{~g}$, 칼슘의 경우 0.6-1.0 g 범위 (성인의 경우 $0.7 \mathrm{~g}$ ), 마그네슘의 경우 0.2-0.7 g 범위, 인의 경우 0.6-0.9 $\mathrm{g}$ 범위 (성인의 경우 $0.7 \mathrm{~g}$ )를 제시하였다. 이러한 일면에서 시제 연어 패티와 시판 패티의 각각 $100 \mathrm{~g}$ 을 섭취하는 경우 건강 기능효과를 기대할 수 있는 일일 섭취량에 대하여 철은 각각 $5.0 \%$ 및 $15.0 \%$, 칼슘(성인 기준)은 각각 $3.6 \%$ 및 $5.6 \%$, 칼륨은 각각 $5.9 \%$ 및 $5.1 \%$, 인은 각각 $30.2 \%$ 및 $20.8 \%$, 마그네 슘 $(500 \mathrm{mg}$ 기준)은 각각 $6.5 \%$ 및 $6.2 \%$ 에 해당하여 인의 보강 효과이외에는 크게 기대할 수 없으리라 판단되었다.

관능검사

튀김 처리한 시판 돈육 패티의 맛, 조직감 및 색조를 기준점 인 4점으로 하고, 시제 연어 패티 제품 (대두유 첨가 연어 패티 및 $\mathrm{DHA}$ 강화 연어 패티)이 이보다 우수한 경우 5-9점으 로, 이보다 못한 경우 3-1점으로 하는 9단계 평점법으로 상대 평가하여 평균값으로 나타낸 결과는 Table 6과 같다. 관능검사 결과 시판 돈육 패티에 비하여 시제 대두유 첨가 연어 패티 및 $\mathrm{DHA}$ 강화 연어 패티는 냄새의 경우 모두 4.0 으로 $5 \%$ 유의수준에서 차이가 없었고, 색조의 경우 각각 7.6점 및 7.5점 으로, 맛의 경우 각각 6.8 점 및 7.4점으로 $5 \%$ 유의수준에서 높은 점수를 받았다. 이와 같이 시제 연어 패티가 시판 돈육 패티에 비하여 색조가 우수한 것은 시제 연어 패티의 제조공 정 중에 유화커드를 첨가함으로 인하여 백색도를 개선하면서 특유의 선홍색을 유지하였기 때문이고, 맛이 우수한 것은 연 어 특유의 맛에 가공 중 첨가한 조미료에 의하여 다소 상승되 었기 때문이라 판단되었다. 한편 시제 연어 패티가 시판 돈육 패티에 비하여 냄새에서 차이가 없었던 것은 연어의 경우 다른 생선에 비하여 비린내가 약하면서 마늘가루, 양파가루 및 생강가루를 첨가하여 제조함으로 인하여 비린내가 마스킹 (masking)되었기 때문이라 판단되었다. 한편 시제 연어 패티 간의 관능검사는 색조, 냄새 및 맛과 같은 모든 항목에서 $5 \%$ 유의수준에서 차이가 없었는데, 이는 단지 유화커드 제조시 첨가한 사용한 지질의 종류 (대두유와 $\mathrm{DHA}$ 농축 오징어 내장 유) 만이 차이가 있었기 때문이라 판단되었다.

\section{참고문헌}

AOAC. 1995. Official Methods of Analysis. 16th ed. Association of Official Analytical Chemists, Washington DC, U.S.A., 69-74.

AOCS. 1990. AOCS Official Method Cd 8-53, in Official Methods and Recommended Practise of the AOCS, fourth edition, vol I. American Oil Chemists Society, Champaign, Illinois, U.S.A.

Bligh EG and Dyer WJ. 1959. A rapid method of lipid extraction and purification. Can J Biochem Physiol 37, 911-917.

Chung CY and Toyomizu MT. 1976. Studies on the 
browning of dehydrated foods as a function of water activity- I. Effect of Aw on browning in amino acid-lipid systems. Bull Japan Soc Sci Fish 42, 697-702.

Erkan N and Ozden O. 2007. Proximate composition and mineral contents in aqua cultured sea bass (Dicentrarchus labrax), sea bream (Sparus aurata) analyzed by ICP-MS. Food Chem 102, 721-725.

Gogus U and Smith C. 2010. n-3 Omega fatty acids: a review of current knowledge. International $\mathrm{J}$ Food Sci Technol 45, 417-436.

Heu MS and Kim JS. 2009. Preparation and characterization of salmon patty using muscle from salmon frame. Kor J Fish Aquat Sci 42, 183-189.

Heu MS, Park SH, Kim HS, Jee SJ, Lee JH, Kim HJ, Han BW and Kim JS. 2007. Improvement on the functional properties of Gomtang-like product from salmon frame using commercial enzymes. J Korean Soc Food Sci Nutr 36, 1596-1603.

Ihm CW, Kim JS, Joo DS and Lee EH. 1992. Processing and quality stability of precooked frozen fish foods. I . Processing of sardine burger. J Korean Agric Chem Soc 35, 254-259.

Joo DS, Cho SY, Kang HJ, Jin DH and Lee CH. 2000. Antimicrobial and antioxidant activity of protamine prepared from salmon spem. Korean J Food Sci Technol 32, 902-907.

Kim JS, Ha JW and Lee EH. 1997. Refining of squid viscera oil. J Korean Agric Chem Soc 40, 294-300.

Kim JS, Heu MS and Ha JH. 2007. Fundamentals and applications of seafood processing. Hyoil Publishing Co., Seoul, Korea, 38-41.

Kim JS, Kim IS, Kim HS, Kang GT, Yeum DM, Ha JW and Heu MS. 2008. Agriculture and Animal Food
Prosessing. Hyoil Publishing Co., Seoul, Korea, 209-222.

Lee JH, Lee KT, Park SM and Park CK. 1998. Improvement of rheological and functional properties of salmon FPC by enzymatic partial hydrolysis. 1 . Production of salmon FPC hydrolysates and their general properties. J Korean Fish Soc 31, 132-138.

Mehta J. 1987. Eicosapentaenoic acid, its relevance in atherosclerosis and coronary heart disease. Am J Cardiol 59, 155-159.

Ministry of Social Welfare of Japan. 1960. Guide to Experiment of Sanitary Infection. III. Volatile basic nitrogen. Kenpakusha, Tokyo, Japan, 30-32.

Park JH and Lee KH. 2005. Quality characteristics of beef jerky meat of various places of origin. Korean J Food Cookery Sci 21, 528-535.

Steel RGD and Torrie H. 1980. Principle and Procedures of Statistics. 1st ed. McGraw-Hill Kogakusha, Tokyo, Japan, 187-221.

The Korean Nutrition Society. 2000. Recommended dietary allowances for Koreans (7th ed.), Chungang Publishing Co., Seoul, Korea, 43-56, 157-218.

Tsutagawa Y, Hosogai Y and Kawai H. 1994. Comparison of mineral and phosphorus contents of muscle and bone in the wild and cultured horse mackerel. J Food Hyg Soc Japan 34, 315-318.

You BJ. 1997. Changes of salmon meat texture during semi-drying process. J Korean Fish Soc 30, 264-270.

2010년 3월 8일 접수

2010년 6월 15일 수정

2010년 8월 13일 수리 